\title{
Efficiency of biological control of Gonipterus platensis (Coleoptera: Curculionidae) by Anaphes nitens (Hymenoptera: Mymaridae) in cold areas of the Iberian Peninsula: Implications for defoliation and wood production in Eucalyptus globulus
}

\author{
Ana Raquel Reis ${ }^{\mathrm{a}, \mathrm{b}}$, Luis Ferreira ${ }^{\mathrm{b}}$, Margarida Tomé ${ }^{\mathrm{a}}$, Clara Araujo ${ }^{\mathrm{b}}$, Manuela Branco ${ }^{\mathrm{a}, *}$ \\ ${ }^{a}$ Centro de Estudos Florestais (CEF), Instituto Superior de Agronomia (ISA), Technical University of Lisbon (UTL), Tapada da Ajuda, 1349-017 Lisbon, Portugal \\ ${ }^{\mathrm{b}}$ Altri Florestal, SA, Quinta do Furadouro, 2510-582 Olho Marinho, Portugal
}

\section{A R T I C L E I N F O}

\section{Article history:}

Received 28 November 2011

Received in revised form 21 January 2012

Accepted 25 January 2012

Available online 20 February 2012

\section{Keywords:}

Economic impact

Biological control

Climate niche

Defoliation

Wood loss

Eucalyptus weevil

\begin{abstract}
A B S T R A C T
Sustainable management of forest plantations and cost-effective control strategies depend on previous estimations of the economic level of damage caused by the pests. The eucalyptus weevil, a key pest of Eucalyptus plantations worldwide, is mainly controlled using classical biological control, using the mymarid egg-parasitoid Anaphes nitens (Girault). Nevertheless, in several temperate regions, the parasitoid fails to reduce the weevil populations to economically sustainable levels. This study attempts to (i) relate the efficiency of the parasitoid with climate variables, (ii) relate the level of damage caused by the weevil with the rate of parasitism, (iii) estimate the implications of weevil damage on wood production. Weevil density, damage caused by defoliation on the upper crown and parasitism rates were monitored in 2007, in 34 Eucalyptus globulus stands. Elevation, temperature and precipitation were assessed by using the Worldclim database. Using historic inventory data, wood production was projected to an age of 10 years, prior to the arrival of the weevil, and compared with current data for the same stands.

Parasitism rate by $A$. nitens was a key element explaining weevil density and tree defoliation, $r^{2}=0.37$ and $0.41(p<0.001)$, respectively. Significant relationships between parasitism rates and maximum temperature of the winter months (MaxTw), $r^{2}=0.55$ and elevation $r^{2}=0.59(p<0.001)$ were found. Other climatic variables, such as temperatures of the warmest months and precipitation, were not significantly related to parasitism rates. An upper threshold limit for the efficiency of the parasitoid appears for MaxTw of $10-11^{\circ} \mathrm{C}$. The mean percentage of parasitism was low $10.1 \%( \pm 4.9)$ for MaxTw below $10^{\circ} \mathrm{C}$, increasing to $70.9 \%( \pm 3.8)$ above $11.5{ }^{\circ} \mathrm{C}$. A reduction of the efficiency of $A$. nitens due to differences in the climatic niches of both the host and the parasitoid is hypothesised. The lower temperature threshold in particular, is of paramount importance for this host-parasitoid system. In consequence, in colder areas MaxTw $<10^{\circ} \mathrm{C}$, a defoliation of $74.1 \%$ was attained. Wood volume (projected to the age of 10 years) was estimated to decrease to $51 \%$ in the affected areas in 2004-2006, compared to the previous period of 1995-1998. Estimated loss in wood volume increased exponentially reaching $43 \%$ and $86 \%$, for $75 \%$ and $100 \%$ of tree defoliation, respectively. Therefore, considering the increase in the economic costs calculated for these regions, due to the high defoliation caused by the weevil, research into alternative control strategies is urgently needed.
\end{abstract}

(c) 2012 Elsevier B.V. All rights reserved.

\section{Introduction}

Pests and diseases seriously threaten the productivity and sustainability of forest plantations. In particular, alien pests and pathogens, either affecting native or exotic forest plantations, are known to cause major economic losses in forestry worldwide (Pimentel et al., 2002). Yet, information on the efficacy of management strategies as well as their economic impact is frequently insufficient (Kenis and Branco, 2010).

\footnotetext{
* Corresponding author. Tel.: +351 213653382; fax: +351 213653388.

E-mail address: mrbranco@isa.utl.pt (M. Branco).
}

Exotic tree species are extensively used in forest plantations worldwide, allowing high-yield wood production and monetary revenue (Sedjo, 1999). In particular, Eucalyptus species are preferred for plantations in many regions for their fast growth, excellent wood-fibre characteristics and tolerance to a wide range of environmental conditions (Campinhos, 1999; Bhattacharya et al., 2003; Stape et al., 2004). In the Iberian Peninsula, Eucalyptus plantations represent an important part of the agricultural landscape. In Spain, 325000 and 175000 ha of Eucalyptus globulus Labill. and Eucalyptus camaldulensis Dehnh., respectively, are planted (Montoya, 1995), and in Portugal eucalyptus plantations represent about $24 \%$ of forest plantations, occupying 740000 ha, mostly 
E. globulus (AFN, 2010). Although exotic forest plantations initially benefit from the release of their co-evolved pests and pathogens, in the longer term such freedom will cease, as eventually the natural enemies will also reach the new regions of establishment of their host plant and compromise plantation health and productivity. Over the past century, several species of insects associated with Eucalyptus trees have found their way all over the world, thus becoming serious pests. For instance in Europe nine alien arthropod pests are currently affecting Eucalyptus plantations (Kenis and Branco, 2010).

The Eucalyptus weevil, referred as Gonipterus scutellatus Gyllenhal (Coleoptera: Curculionidae) in the literature, is a major pest of Eucalyptus plantations worldwide, and both the larvae and the adults feed on Eucalyptus leaves. However, recent taxonomic and genetic studies revealed that this name refers to a complex of several cryptic species, originating from different regions in Australia (Newete et al., 2011; Mapondera et al., 2012). According to these studies, the species found in the Iberian Peninsula is not $G$. scutellatus but G. platensis Marelli, which was described from Argentina although being native from Tasmania. Further, the Gonipterus species introduced in Italy in 1975 and in South-eastern France in 1977, is not G. platensis (Mapondera et al., 2012), thus indicating the occurrence of multiple introductions in Europe of Gonipterus spp.

In South Africa, Gonipterus spp. referred as G. scutellatus (Tooke, 1953), and now identified as a different, but still undescribed species (Newete et al., 2011; Mapondera et al., 2012), was at the beginning, considered a problem to eucalyptus forestry. Biological control of the weevil started when an egg-parasitic wasp Anaphes nitens Girault (Hymenoptera: Mymaridae) was first introduced in South Africa in 1926 (Tooke, 1953). From South Africa, after the initial success of the agent, the parasitoid was introduced into many other regions over the world, usually with at least partial success (e.g., Cordero Rivera et al., 1999; Hanks et al., 2000). Nevertheless, in temperate regions of South Africa, Western Australia and the Iberian Peninsula, the damage caused by the eucalyptus weevil remains high, despite the presence of the parasitoid (Loch and Floyd, 2001; Valente et al., 2004; Tribe, 2005; Govender and Wingfield, 2005; Echeverri-Molina and Santolamazza-Carbone, 2010). Both in Portugal and in Galicia, Spain, G. platensis became a major limiting factor of Eucalyptus wood production, prompting recent research programs to cope with this insect pest through either tree resistance (Basurco and Toval, 2004), chemical control (Santolamazza-Carbone and Fernandez, 2004; Echeverri-Molina and Santolamazza-Carbone, 2010), or seasonal augmentative release of $A$. nitens, as conducted by Altri Florestal enterprise since 2006.

Despite the recognized loss of productivity caused by G. platensis, little is known about the impact of defoliation on tree growth in the Iberian Peninsula. Reliable estimates of tree growth reduction due to a specific agent, face a major difficulty since they require the control of other factors influencing tree susceptibility and tolerance, such as soil, climate as well as other biotic interactions. Chemically treated control trees have been used by some researchers to estimate defoliation impact on tree growth (e.g., Salleo et al., 2003; Loch and Matsuki, 2010). However, in Gonipterus a preference of the adults to oviposit on leaves of chemically treated plants in the weeks following treatment and the combined damage done by both larvae and adults, mask the true defoliation impact when compared with non-chemically treated plants (Palma and Valente, 2008). The factors responsible for the low efficiency of the parasitoid $A$. nitens in some regions are still poorly understood, although some studies indicate differences in parasitism rate related to season, or host density (Cordero Rivera et al., 1999; Loch, 2008). In the present study we assess the damage caused by $G$. platensis and its relationship with the efficiency of the parasitoid, in relation to site climate variables, in particular monthly temperatures and precipitation. We further use recent historical data, collected previously to the arrival of the weevil and current inventory data from the same stands, to estimate the wood loss caused by G. platensis and determine its possible economic impact.

\section{Methods}

\subsection{Field surveys: site description}

During 2007, 34 pure stands representative of the Eucalyptus young plantations of the northern and central regions of Portugal, were monitored. These plantations of E. globulus occupy 2300 ha (Fig. 1) and present the highest levels of attack by G. platensis observed in Portugal (Valente et al., 2004). Stands were pure even-aged, varying between two and five years old. Tree mean height varied between 2 and $5 \mathrm{~m}$ across stands. Further, each stand was genetically highly uniform, since all plants originated from the same family. Each of the stands selected was systematically sampled based on a $500 \times 1000 \mathrm{~m}$ grid (ca. 1 plot per each $50 \mathrm{ha}$ ), therefore depending on total stand area, 1 to 6 plots resulted per stand. According to this procedure, a total of 64 plots were sampled across the 34 stands. The plots sampled were neither affected by pests other than G. platensis, nor by pathogens, in a conspicuous way.

The elevation of the plots sampled ranged from 290 to $900 \mathrm{~m}$. Monthly mean, maximum and minimum temperature and precipitation were taken from the WORLDCLIM datasets (Hijmans et al., 2005; http://www.worldclim.org). This data set was derived from the average monthly temperatures and precipitation, measured between 1950 and 2000, by a network of meteorological stations, from which climate surfaces were estimated by very high resolution interpolation, at a resolution of about $1 \mathrm{~km}^{2}$. To interpolated climate surfaces the model considers elevation as a variable (Hijmans et al., 2005). This is most relevant for the present study, given that the studied region is mountainous, where elevation has a major influence on climate. The network of national meteorological stations could not provide accurate information, since the nearest meteorological stations were at dissimilar elevations and at a mean distance from the sample points of about $50 \mathrm{~km}$. No climate extrapolation model at national level was available. Based on Worldclim estimates, minimum, mean and maximum temperatures of the three warmest (MinTs, MeanTs, MaxTs) and of the three coldest months (MinTw, MeanTw, MaxTw) were calculated.

\subsection{Population density and defoliation level}

The densities of adults, larvae and the number of egg masses of G. platensis in each plot were sampled by choosing an initial point at the centre of the plot, from which three trees, about $125 \mathrm{~m}$ apart, were selected along a row, thus minimizing spatial autocorrelation.

The number of adult weevils per tree was estimated by bending and shaking trees over a $2 \mathrm{~m}$ wide plastic sleeve, and collecting fallen weevils. This was possible due to the relatively small tree size and trunk flexibility of the young trees. When a tree was impossible to bend, a plastic sheet was placed around its base and it was hit with a pole. Quick and strong strokes were found to dislodge the weevils, preventing them from gripping thigh, or flying away. The relative density of the adults was scored according to the following scale: (0) no weevils; (1) 1-20 weevils; (2) 21-30 weevils; (3) >30 weevils.

In each tree, the number of young branches with newly formed leaves, preferred by the weevil for oviposition, was counted. On two branches of the upper crown of the tree with newly formed leaves, which were taken from opposite quadrants of the trees, 


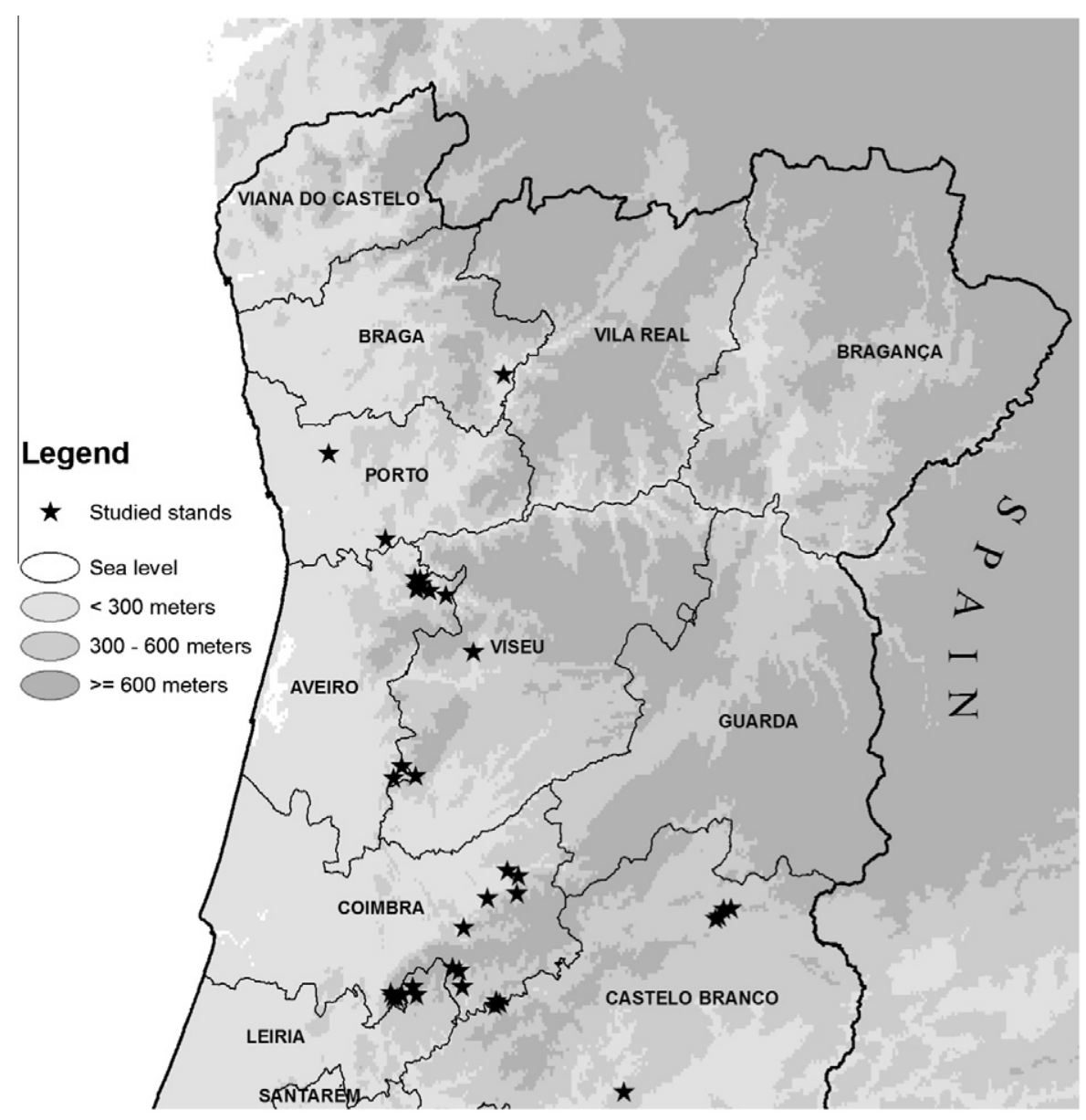

Fig. 1. Site location of 34 Eucalyptus globulus stands monitored in spring (2007) in northern and central Portugal.

the total number of larvae and egg capsules were counted by carefully inspecting all the leaves. The total number of larvae and egg capsules per tree was then estimated by extrapolating of the total number of branches with newly formed leaves. Population sampling was made in February 2007, at the peak of the weevil egg laying activity, as observed during previous field surveys.

In June, after the spring damage, defoliation levels were estimated in the plots sampled. In each plot, 10 trees were selected, the first one located at the centre of the stand and the other nine by following a line of trees, along which one tree was selected approximately every $10 \mathrm{~m}$. The percentage of defoliation was estimated in the upper third of the canopy by visual observation and comparison with calibrated photographs, considering four levels of damage: (0) no defoliation; (1) 1-30\% defoliation; (2) $30-75 \%$ defoliation; ( 3 ) $>75 \%$ defoliation. Only the upper third of the canopy, containing new flushing foliage, was considered because it represents the section of plant where severe defoliation has taken place during the spring season.

\subsection{Parasitism rates}

In each plot, 30 egg capsules were collected from five trees, located about $125 \mathrm{~m}$ apart and selected using the same procedure as for the trees sampled for weevil density. Only fresh egg capsules, recognised by their texture, taken from newly foliage, and with no exit holes were collected. Egg capsules were taken to the laboratory to estimate parasitism levels, and kept at about $5{ }^{\circ} \mathrm{C}$ in a refrigerated chamber during transportation to avoid dehydration.

In the laboratory, each egg capsule was placed in a Petri dish sealed with parafilm, appropriately identified and stored in a climate chamber $\left(22 \pm 0.5^{\circ} \mathrm{C} 14 \mathrm{hL}: 20 \pm 0.5{ }^{\circ} \mathrm{C} 10 \mathrm{hD}\right.$; RH: $\left.55 \%\right)$. The number of adults of $A$. nitens which emerged and the number of weevil larvae which hatched were recorded for each egg capsule, over 30 days. Egg capsules with no emergences, either larvae or wasps, were excluded from the analysis. The rate of parasitism was estimated as the percentage of egg capsules with A. nitens emergences. The application of this variable is straightforward and it is highly correlated with the mean number of wasps emerged per egg mass $\left(r^{2}=0.916, p<0.001\right)$.

\subsection{Wood production loss}

Estimates of wood production loss were based on AltriFlorestal enterprise forest inventory, using data from 31 pure, even-aged $E$. globulus stands, distributed over the same region where the forest plantation used in this study is located. Inventory data comprised tree height and diameter at breast height ( $\mathrm{dbh}$ ) from all trees within $900 \mathrm{~m}^{2}$ plots. For each stand, inventory data referring to two periods were considered: (1) 1995 to 1998, before the establishment of G. platensis and (2) 2004 to 2006, after the establishment of $G$. platensis. Stand age varied from 2 to 10 years.

Defoliation levels were assessed in 2007 by surveying the 31 inventory stands, using the same methods described in section 2.2. This expressed the intensity of damage at site level, as from our previous field surveys the populations of G. platensis and defoliation levels, were kept at similar levels within each site across years. Of the 31 stands surveyed in 2007, 18 denominated $U$ stands (undamaged), were not visibly affected by the weevil having a zero defoliation level, whereas $13 \mathrm{D}$ stands (damaged) experienced visible defoliation, ranging from medium to severe. 
The inventory data from 1995-1998 and 2004-2006 were projected onto the rotation age ( 10 years) using an empirical growth model, in order to estimate dominant height (mean tree height of the largest 100 trees per ha) and merchantable volume at harvest. This model is operationally used by AltriFlorestal company and was developed by M. Tomé (unpublished) (Table Appendix 1). Using the same inventory stands, along with the projections of the estimated merchantable volume at 10 years in the two periods of time (1995-1998 and 2004-2006), we calculated the loss of merchantable volume caused by the presence of $G$. platensis, as a percentage. This loss of production was then related to the level of damage observed in the same plots, in 2007 by curve fitting.

\subsection{Data analysis}

The levels of density of the adult weevils, larvae and egg capsules obtained, as explained in section 2.2., were extrapolated by multiplying the mean number per branch by the number of branches with newly foliage to obtain an estimation of density per tree and then an average of density per tree, at plot level.

Average tree defoliation was expressed as percentage of defoliation of the third upper crown. Parasitism rates were given by the average percentage of parasitized egg capsules per plot sampled. A Generalized Linear Model, type III mean squares, was used to analyze differences between stands, on the following predictor variables: adult density, larva density and egg capsule density. A Poisson distribution with log link function was used and the results were presented in Wald Chi-square (W), degrees of freedom (df) and p-value. Pearson's correlations were estimated to assess the relationship between population density, parasitism rate and site variables. Lack of fit tests were performed for the linear regression between these variables and defoliation. Non-parametric Spearman correlation $\left(r_{\mathrm{s}}\right)$ was instead used, when lack of fit of a linear model was observed. Pairwise t-test were applied to compare dominant height $(\mathrm{dh})$ and merchantable volume projected to 10 -years of age $\left(\mathrm{Vm}_{10}\right)$, between the two periods: $1995-1998$, before establishment of the weevil, and 2004-2006, after the establishment of the weevil; tests were applied independently on both types of stands, currently defoliated (D) and undamaged (U). For current defoliated stands, the loss of merchantable volume as dependent variable in function of defoliation was fitted through curve estimation. Linear, power, logarithmic and exponential functions were tested, the function providing the best fit being selected. All analyses were performed with SPSS 18.0 software for Windows (SPSS Inc., Chicago, IL, USA). The results were considered statistically significant at $p<0.05$. Data are presented as means \pm standard error.

\section{Results}

\subsection{Weevil density and defoliation damage}

Significant differences between stands were found for the mean number of egg capsules ( $W=100.57$; $\mathrm{df}=28 ; p<0.001$ ), weevil larval density $(W=133.68 ; \mathrm{df}=33 ; p<0.001)$ and weevil adult density $(W=184.60 ; \mathrm{df}=33 ; p<0.001)$.

Average defoliation of the upper third of the canopy in the spring of 2007 was $55.5 \% \pm 3.3, n=64$. The intensity of damage measured in June increased with the density of adults, larvae and egg capsules estimated in February (Fig. 2). Additionally, adult density in February gave the best prediction of spring season defoliation levels $\left(r^{2}=0.77, F_{1,62}=204.25, p<0.001\right)$. The results showed no lack of fit for the linear regression model for this variable $\left(F_{8,54}=0.708\right.$, $p=0.591)$. A lower correlation between larvae and late season defoliation was observed although it was still significant (Fig. 2). A

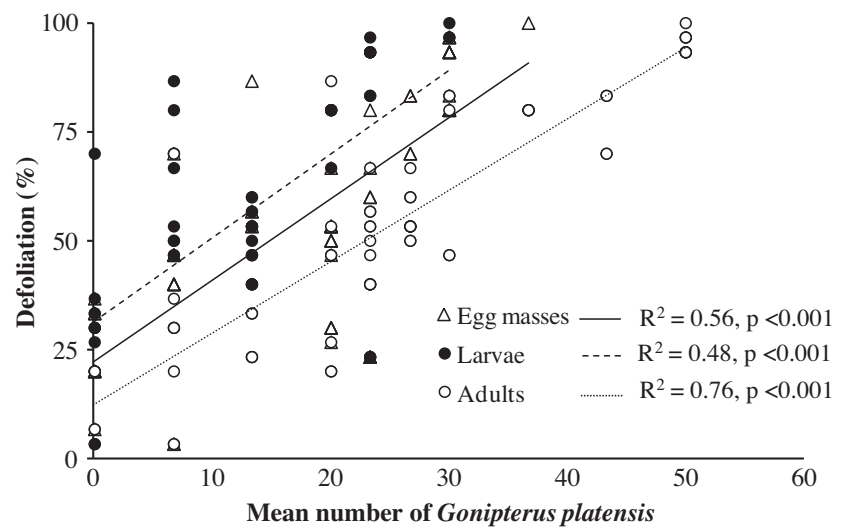

Fig. 2. Average defoliation (\%) of the upper third of the tree canopy of Eucalyptus globulus, observed in June 2007, in relation to the average number of egg masses, larvae and adult of G. platensis estimated in February 2007, on 64 plots located in northern and central Portugal.

significant lack of fit for the linear regression of spring defoliation in function of both larvae $\left(F_{4,58}=4.405, p=0.004\right)$ and egg masses $\left(F_{6,56}=6.109, p<0.001\right)$ was observed. Yet, Spearman correlations with defoliation were significant, $r_{\mathrm{s}}=0.694 ; r_{\mathrm{s}}=0.751 p<0.001$, for larvae and egg masses, respectively.

Defoliation level increased with elevation $\left(r^{2}=0.48, F_{1,62}=\right.$ 57.81, $p<0.001)$ and precipitation $\left(r^{2}=0.21, F_{1,62}=16.49, p\right.$ $<0.001$ ). On the other hand, defoliation was negatively correlated with the average temperature of the three coldest months (MaxTw) $r^{2}=33, F_{1,62}=30.16, p<0.001$, and of the three warmest months (MaxTs) $r^{2}=0.30, F_{1,62}=26.75, p<0.001$. The average defoliation was $74.1 \pm 7.7 \%$ for sites exhibiting MaxTw below $10^{\circ} \mathrm{C}$, whereas it decreased to $33.5 \pm 4.8 \%$ for sites where MaxTw surpassed $11.5^{\circ} \mathrm{C}$.

\subsection{Parasitism rates by nitens}

The number of wasps emerging per egg capsule ranged from 0 to 14 , with a mean of $2.22 \pm 3.21$. Parasitism rates varied from 0 to $100 \%$, with a mean of $44.1 \pm 3.9 \%$. Significant negative correlations of $-0.61,-0.42$ and $-0.64(p<0.001)$ were found between the rates of parasitism and the density of adult weevils, egg capsules and defoliation levels, respectively. Also the parasitism rate correlated negatively with elevation (Table 1 ). Above $700 \mathrm{~m}$ elevation, the mean percentage of parasitism was $14.7 \pm 3.9 \%$, whereas below $400 \mathrm{~m}$ it was $76.6 \pm 10.2 \%$.

The analysis of the climatic variables showed that the maximum temperature of the three coldest months was the variable that could better explained the differences in parasitism rates observed among plots, whereas correlations with temperatures of the three warmest months and total precipitation, were not significant (Table 1). Maximum temperatures of the three coldest months (MaxTw) between 10 and $11^{\circ} \mathrm{C}$ evidenced a threshold limit (Fig. 3). Below $10^{\circ} \mathrm{C}$ of MaxTw, parasitism rates were extremely low and independent of the temperature $\left(F_{1,7}=0.221, p=0.653\right)$, whereas above this threshold parasitism rates increased significantly with temperature $\left(F_{1,53}=39.257, p<0.001\right)$. For sites with

\section{Table 1}

Pearson correlation, $r$, between the parasitism rate and the climatic variables: maximum and minimum temperatures of the three coldest (MaxTw, MinTw) and warmest (MaxTs, MinTs) months, and total rainfall (Rain) and elevation.

\begin{tabular}{lrrllll}
\hline & MaxTw & MinTw & MaxTs & MinTs & \multicolumn{1}{l}{ Rain } & Elevation \\
\hline$r$ & 0.741 & 0.554 & 0.345 & 0.171 & -0.173 & -0.760 \\
$p$-value & $<0.001$ & $<0.001$ & 0.052 & 0.177 & 0.172 & $<0.001$ \\
\hline
\end{tabular}


MaxTw below $10^{\circ} \mathrm{C}$, the mean parasitism rate was $10.1 \pm 4.9 \%$, ranging from 0 to $45 \%$, whereas at MaxTw above $11.5^{\circ} \mathrm{C}$ it was $70.9 \pm 3.8 \%$, ranging from 50 to $100 \%$ (Fig. 3 ).

\subsection{Wood production loss}

A significant decrease in both dominant height ( $d h)$ and merchantable volume, projected to 10 years of age, was observed in the stands currently attacked by the weevil (D) in comparison with the values obtained for the same stands before establishment of the weevil (1995-1998). Losses in $d h$ and merchantable volume in currently attacked plantations were estimated to be on average, about $29 \%$ and $51 \%$, respectively (Table 2 ). In contrast, wood productivity did not decrease in the stands currently not attacked by the weevil (U); in fact a slight increase in merchantable volume and $d h$ was observed in recent stands in comparison with historical ones, although the differences were not significant (Table 2).

When the stands under current attack by the weevil (D) are considered, an exponential increase of wood loss as a function of the intensity of defoliation provide the best fit $\left(R^{2}=0.83\right.$; $p<0.001$ ) (Fig. 4). For 50 and $75 \%$ of the defoliation of the upper third canopy, the predicted loss in merchantable volume was 21 and $42 \%$, respectively. This production loss increased substantially to $86 \%$ when defoliation was $100 \%$, as frequently observed in stands located above $700 \mathrm{~m}$ of elevation in the study area.

\section{Discussion}

Knowledge of the impacts of forest pests, as well as the efficacy of pest management strategies is essential for forest managers. Classical biological control using co-evolved natural enemies is one of the most promising management tools for the control of exotic pests. Nevertheless, besides other inherent risks (van Lenteren et al., 2003), the efficiency of the biological control organism is not always satisfactory. Over $80 \%$ of the organisms released for the biological control of arthropods do not result effective (Hall et al., 1980). Understanding the reasons for such failures will contribute to improve the efficacy of biological control programs. The parasitoid $A$. nitens is the main agent used worldwide to control the eucalyptus weevil (Hanks et al., 2000; Paine et al., 2000; Sanches, 2000). Nevertheless, in regions of Galicia (Spain) and of northern and central Portugal, the damage caused by the weevil is above the level of economic acceptance, despite successive releases of the parasitoid by public and private forest enterprises (Cordero Rivera et al., 1999; Valente et al., 2004). Inefficient rates of parasitism by A. nitens were also recorded in some areas of South Africa (Tribe, 2005) and southwestern Australia (Loch, 2008). Possible reasons for the reduced efficacy of the parasitoid have been

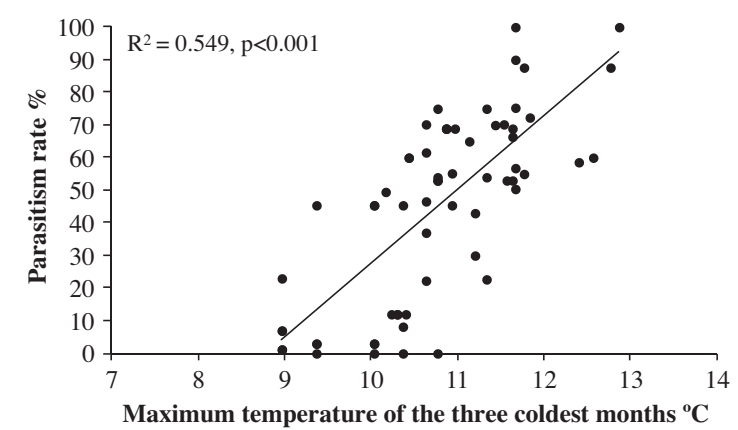

Fig. 3. Relationship between parasitism rate and maximum temperature observed during the three coldest months of the year (December, January and February), calculated from WorldClim monthly datasets, and from 64 plots located in northern and central Portugal.
Table 2

Dominant height $(\mathrm{dh})$ and merchantable volume projected to 10-years of age $(\mathrm{Vm})$, \pm SE, in two types of stands, currently defoliated (D) and undamaged (U) by $G$. platensis, and two periods: 1995-98 before establishment of the beetle; 2004-06, after establishment, in the northern and central regions of Portugal. For the same stand category, different letters indicate significant differences, t-test $(p<0.05)$.

\begin{tabular}{lllllll}
\hline \multicolumn{3}{l}{ Defoliated stands - D } & \multicolumn{4}{c}{ Undamaged stands - U } \\
\hline & $1995-98$ & $2004-06$ & $\Delta \%$ & $1995-98$ & $2004-06$ & $\Delta \%$ \\
$d h$ & $21.6^{\mathrm{a}} \pm 0.5$ & $15.4^{\mathrm{b}} \pm 1.4$ & -28.6 & $19.9^{\mathrm{a}} \pm 0.5$ & $21.4^{\mathrm{a}} \pm 0.6$ & +7.5 \\
$V m$ & $141.3^{\mathrm{a}} \pm 7.6$ & $69.8^{\mathrm{b}} \pm 10.5$ & -50.6 & $114.8^{\mathrm{a}} \pm 9.0$ & $115.3^{\mathrm{a}} \pm 6.8$ & +0.4 \\
\hline
\end{tabular}

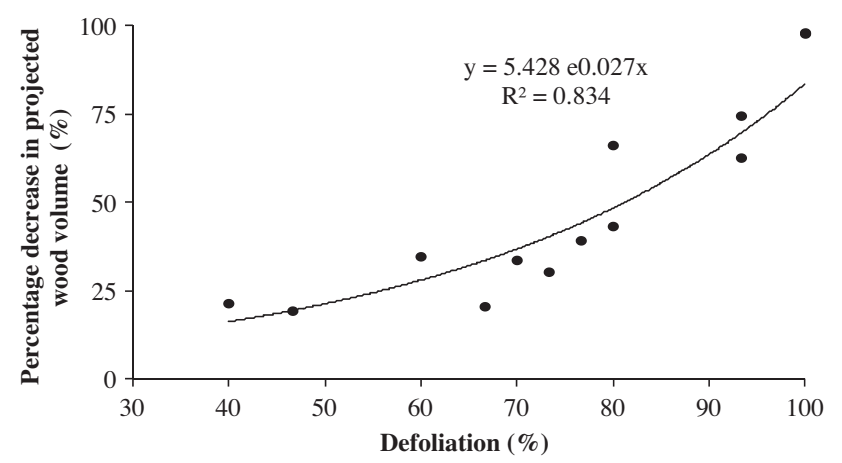

Fig. 4. Relationship between the level of damage by G. platensis and the decrease in the projected merchantable volume (\%) at age 10 years in Eucalyptus globulus stands in northern and central regions of Portugal.

suggested, such as microclimatic conditions and fluctuations in the population dynamics of both the host and parasitoid (Cordero Rivera et al., 1999; Santolamazza-Carbone and Fernandez, 2004; Loch, 2008). Since $A$. nitens is highly host specific, it has been suggested that high parasitism rates may lead to a local extinction of the host and consequently to the collapse of the A. nitens population, originating a release of the weevil from the parasitoid in the next generation (Cordero Rivera et al., 1999). In the present study, the mean parasitism rates varied between 0 and $100 \%$. High parasitism rates were observed only at sites with low elevation, where G. platensis was under control. In effect, mean parasitism reached $100 \%$ in two sites, located at 430 and 290 m elevation, in which mean defoliation was low, 6.7 and $20 \%$, respectively. Therefore, the hypothesis of host-parasitoid population disruption by high parasitism rates was not observed in this study.

In the present study, the rate of parasitism by A. nitens and consequent efficient control of $G$. platensis, were found to vary along an altitudinal range, decreasing steeply with elevation, as previously observed by Valente et al. (2004). Analysis of the climatic variables showed that the parasitism rate was most strongly correlated with temperature of the warmest hours of the day, during the three coldest months $(r=0.74)$, whereas no significant relationship with temperatures during the summer months, or with precipitation was found. Maximum temperatures of the three coldest months, between 10 and $11^{\circ} \mathrm{C}$, were found to set the lower threshold for the efficiency of the parasitoid. The fact that parasitism ranges from 0 to $45 \%$ in regions with maximum winter temperatures below $10{ }^{\circ} \mathrm{C}$, but from 50 to $100 \%$ under temperatures equal, or above, $12{ }^{\circ} \mathrm{C}$ (Fig. 3 ) indicates that $A$. nitens is ineffective at low temperatures, below $10^{\circ} \mathrm{C}$, such as those prevailing during the winter and early spring months. Precipitation does not seem to be a relevant variable since it did not correlate significantly with the rate of parasitism. Other regions where the parasitoid fails to efficiently control the eucalyptus weevil also experience climates with coldtemperate winters, confirming that low temperatures might be a limiting factor for this host-parasitoid system (Cordero Rivera 
et al., 1999; Tribe, 2005). However, this system is also considered to be "unnatural", as A. nitens originates from South Australia (Tooke, 1953), a region with a warm to mild climate, whereas G. platensis is native from Tasmania (Mapondera et al., 2012), a region with a colder climate. Adaptation of parasitoid and host to different climatic niches, in particular regarding low-temperature thresholds, may thus explain the failure of $A$. nitens to achieve high parasitism rates in colder areas, or times of the year. In agreement with this hypothesis, G. platensis in our field observations started oviposition in mid-January and February, when average maximum temperatures are below $10^{\circ} \mathrm{C}$, thus precluding $A$. nitens from becoming active. The geographical mismatch between $G$. platensis and $A$. nitens therefore seems to arise from different climatic preferences and temperature thresholds. On the contrary, in other regions such as South Africa, no geographical/ evolutionary mismatch between A. nitens and its Gonipterus host exists, since both are native to South Australia (Rolf Oberprieler, com. pers.).

Average crown defoliation decreased with higher winter temperatures and increased with elevation, to an average of $75 \%$ at elevations above $700 \mathrm{~m}$. This result, as well as the negative relationship found between parasitism and weevil population density, are most probably indirect effects of the low efficiency of the parasitoid, under colder conditions. In contrast, the positive correlation detected between defoliation and precipitation may be due to a higher tree primary productivity (higher new-flush biomass available for the weevil) in the summer.

Determination of the impact of high levels of defoliation on wood production is crucial but difficult and frequently confounded by several factors, depending on the particular insectplant system. In the present study we used an empirical growth model applied to historical and current inventory data, before and after the establishment of $G$. platensis in the study area, in 1999. Results predict a high impact of the defoliation caused by the weevil on the productivity of E. globulus plantations, as projected to 10 years of age, leading to an average loss of $51 \%$ in merchantable volume in the affected stands. Wood volume losses increased exponentially with tree defoliation $\left(R^{2}=0.84\right), 43 \%$ and $86 \%$ losses being projected for $75 \%$ and $100 \%$ defoliation, respectively. The high wood loss observed may be due, in part, to the continuous feeding of the weevils during the spring and autumn, as well as to the continuous growth of the trees, and it further suggests that fast-growing trees may be at higher risk of decreased wood production due to severe defoliation. Our results apparently contradicts previous findings that defoliation by Gonipterus weevils has a limited impact on growth of E. globulus (Loch and Matsuki, 2010). In this study however, defoliation estimates of $18-33 \%$ were calculated for the growing tip of the trees affected, whereas mean defoliation of the control group remained at $5-16 \%$. Nevertheless, even for this moderate defoliation, Loch and Matsuki (2010) estimated a significant impact of defoliation on tree growth over a 2.5-year period. Also, Pinkard et al. (2006) found that as little as a $20 \%$ defoliation of three-year-old E. globulus, resulted in significant reductions of stem growth, within one year only after defoliation. In our study, defoliation was far more severe, ranging from 75 to $100 \%$ in the most seriously affected areas. A value of $50 \%$ defoliation resulted in a decrease of wood loss production of up to $21 \%$.

Despite such high values, wood loss is probably underestimated. The growth model projected wood volume to a tree age of 10 years, considering the dominant height and stand basal area measured at a given age, but the model disregards the effect of defoliation on the future growth of the trees. However, consecutive reduction of leaf surface, essential for tree growth, will also impact negatively during several post-defoliation years (Kulman, 1971). Secondly, successive defoliation events are likely to occur in the years following the inventories, accounting for further reduction in growth.

Field monitoring, to anticipate future plantation damage may thus be most helpful to decision makers. In the present study we found that the population of adult weevils at the end of winter was significantly linearly related to the percentage of defoliation at the end of spring. Therefore, field monitoring of adult weevils may constitute a planning tool of pest management decisions, for this particular insect-plant system.

As observed in other regions, efficient parasitism by $A$. nitens results in low damage by the weevils at low elevations with warmer climates. However, in Portugal, about $1 / 3$ of the eucalyptus plantations are located in central and northern regions above $450 \mathrm{~m}$ elevation, in which the estimated wood loss is severe. In light of the high economic cost uncovered by the present work, we advocate research on control strategies alternative to classical biological control with $A$. nitens, for these regions. Given the evident mismatch between the parasitoid and host, the logical strategy will be to look for natural ("co-evolved") parasitoid species, native from the same geographical region.

\section{Acknowledgements}

We thank AltriFlorestal for supporting this study through a collaboration protocol with ISA-UTL and Dr. Rolf Oberprieler (CSIRO Ecosystem Sciences, Canberra, Australia) for comments on an earlier version of this article. Additional funding support was provided by the Portuguese Science Foundation (FCT) through project PTDC/ AGR-CFL/111877/2009.

\section{Appendix A. Supplementary data}

Supplementary data associated with this article can be found, in the online version, at doi:10.1016/j.foreco.2012.01.038.

\section{References}

AFN (Autoridade Florestal Nacional) 2010. Inventário Florestal. Lisboa, Direcção Nacional de Gestão Florestal, Inventário Florestal Nacional - Apresentação de Resultados.

Basurco, F., Toval, G. 2004. Estimated genetic parameters and breeding values for resistance against Gonipterus scutellatus in 13-year-old Eucalyptus globulus in northwest Spain. In: Borralho et al. (2004). Eucalyptus in a Changing World. Proc of IUFRO Conf. Aveiro 11-15 Outubro 2004

Bhattacharya, S.C., Salam, P.A., Pham, H.L., Ravindranath, N.H., 2003. Sustainable biomass production for energy in selected Asian countries. Biomass and Bioenergy 25, 471-482.

Campinhos Jr, E., 1999. Sustainable plantations of high-yield shape Eucalyptus trees for production of fiber: the Aracruz case. New Forests 17, 129-143.

Cordero Rivera, A., Santolamazza-Carbone, S., Andrés, J.A., 1999. Life cycle and biological control of the Eucalyptus snout beetle (Coleoptera, Curculionidae) by Anaphes nitens (Hymenoptera, Mymaridae) in north-west Spain. Agricultural and Forest Entomology 1, 103-109.

Echeverri-Molina, D., Santolamazza-Carbone, S., 2010. Toxicity of synthetic and biological insecticides against adults of the Eucalyptus snout-beetle Gonipterus scutellatus Gyllenhal (Coleoptera: Curculionidae). Journal of Pest Science 83 (3), 297-305.

Govender, P., Wingfield, M.J. 2005. Overview on the entomological research in the Mediterranean forest ecosystems of South Africa. In: Entomological Research in Mediterranean Forest Ecosystems. Lieutier, F.; Ghaioule, D., (Eds.), pp: 43-52. INRA. Paris.

Hall, R.W., Ehler, L.E., Bisbabri-Ershadi, B., 1980. Rate of success in classical biological control of arthropods. Journal of the Entomological Society of America 26, 111-114.

Hanks, L.M., Millar, J.G., Paine, T.D., Campbell, C.D., 2000. Classical biological control of the Australian beetle Gonipterus scutellatus (Coleoptera: Curculionidae) in California. Biology Control 29, 269-375.

Hijmans, R.J., Cameron, S.E., Parra, J.L., Jones, P.G., Jarvis, A., 2005. Very high resolution interpolated climate surfaces for global land areas. International Journal of Climatology 25, 1965-1978.

Kenis, M., Branco, M., 2010. Chapter 5: Impact of alien terrestrial arthropods in Europe. In: Roques, A., et al. (Eds.), Alien terrestrial arthropods of Europe. BioRisk 4(1), 51-71. 
Kulman, H.M., 1971. Effects of insect defoliation on growth and mortality of trees. Annual Review of Entomology 16, 289-324.

Loch, A.D., 2008. Parasitism of the Eucalyptus weevil, Gonipterus scutellatus Gyllenhal, by the egg parasitoid Anaphes nitens Girault in Eucalyptus globulus plantations in southwestern Australia. Biological Control 47, 1-7.

Loch, A.D., Matsuki, M., 2010. Effects of defoliation by Eucalyptus weevil, Gonipterus scutellatus, and chrysomelid beetles on growth of Eucalyptus globulus in southwestern Australia. Forest Ecology and Management 260, 1324-1332.

Loch, A.D., Floyd, R.B., 2001. Insect pests of Tasmanian blue gum, Eucalyptus globulus globulus, in south-western Australia: history, current perspectives and future prospects. Austral Ecology 26, 458-466.

Mapondera, T.S., Burgess, T., Matsuki, M., Oberprieler, R.G., 2012. Identification and molecular phylogenetics of the cryptic species of theGonipterus scutellatus complex (Coleoptera: Curculionidae: Gonipterini). Australian Journal of Entomology. doi:10.1111/j.1440-6055.2011.00853.x.

Montoya, J.M., 1995. El eucalipto. Mundi-Prensa, Madrid, pp. 125.

Newete, S.W., Oberprieler, R.G., Byrne, M.J., 2011. The host range of the Eucalyptus Weevil, Gonipterus "scutellatus" Gyllenhal (Coleoptera: Curculionidae), in South Africa. Annals of Forest Science 68, 1005-1013.

Paine, T.D., Dahlsten, D.L., Millar, J.G., Hoddle, M.S., Hanks, L.M., 2000. UC scientists apply IPM techniques to new eucalyptus pests. California Agriculture 54, 8-13.

Palma, C., Valente, C., 2008. Efeito do gorgulho do eucalipto, Gonipterus scutellatus, no crescimento das plantas. In: Branco, M., Valente, C., Paiva, M.R. (Eds.), Pragas e doenças em Pinhal e Eucaliptal - Desafios para a sua gestão integrada. ISAPress, Lisboa, pp. 87-103.

Pimentel, D., McNair, S, Janecka, J., Wightman, J, Simmonds, C, O'Connell, C. Wong, E., Russel, L., Zern, J., Aquino, T., Tsomondo, T. 2002. Economic and environmental threats of alien plant, animal and microbe invasions. pp. 307330 In: Pimentel, D. (Ed.), Biological Invasions. Economic and Environmental costs of Alien Plants, Animal and Microbe Species. Boca Raton, USA, CRC Press.

Pinkard, E.A., Baillie, C., Patel, V., Mohammed, C.L., 2006. Effects of fertilising with nitrogen and phosphorus on growth and crown condition of Eucalyptus globulus Labill. experiencing insect defoliation. Forest Ecology and Management 231, 131-137.
Salleo, S., Nardini, A., Raimondo, F., Lo Gullo, M.A., Pace, F., Giacomich, P., 2003. Effects of defoliation caused by the leaf miner Cameraria ohridella on wood production and efficiency in Aesculus hippocastanum growing in northeastern Italy. Trees: Structure and Function 17, 367-375.

Sanches, M.A. 2000. Parasitismo de ovos de Gonipterus scutellatus Gyllenhal, 1833 e Gonipterus gibberus Boisduval, 1835 (Coleoptera, Curculionidae) por Anaphes nitens Girault, 1928 (Hymenoptera, Mymaridae) em Colombo (Pará, Brasil). Revista Arquivos do Instituto Biológico 67, 77-82.

Santolamazza-Carbone, S., Fernandez, A.M.F.J., 2004. Testing of selected insecticides to assess the viability of the integrated pest management of the Eucalyptus snout-beetle Gonipterus scutellatus in north-west Spain. Journal of Applied Entomology 128, 620-627.

Sedjo, R.A., 1999. The potential of high-yield plantation forestry for meeting timber needs. New Forests 17, 339-359.

Stape, J.L., Binkley, D., Ryan, M.G., 2004. Eucalyptus production and the supply, use and efficiency of use of water, light and nitrogen across a geographic gradient in Brazil. Forest Ecology and Management 193, 17-31.

Tooke, F.G.C., 1953. The Eucalyptus snout beetle Gonipterus scutellatus Gyll - a study of its ecology and control by biological means. Entomology Memoirs, Department of Agriculture, Union of South Africa 3, 1-282.

Tribe, G.D., 2005. The present status of Anaphes nitens (Hymenoptera: Mymaridae), an egg parasitoid of the Eucalyptus snout beetle Gonipterus scutellatus, in the Western Cape Province of South Africa. Southern African Forestry Journal 203. 49-54.

Valente, C., Vaz, A., Pina, J., Manta, A., Sequeira, A., 2004. Control strategy against the Eucalyptus snout beetle, Gonipterus scutellatus Gyllenhal (Coleoptera, Curculionidae), by the Portuguese Cellulose Industry. In: Borralho, N.M., Pereira, J.S., Marques, C., Coutinho, J., Madeira, M., Tomé, M. (Eds.), Eucalyptus in a Changing World. Procedings of IUFRO Conference, Aveiro, pp. 622-627.

van Lenteren, J., Babendreier, D., Bigler, F., Hokkanen, H.M.T., Kuske, S., Loomans, A.J.M., Menzler-Hokkanen, I., van Rijn, P.C.J., Thomas, M.B., Tommasini, M.G., Zeng, Q.-Q., 2003. Environmental risk assessment of exotic natural enemies used in inundative biological control. BioControl 48, 3-38. 